\title{
Diyabete Bağlı Kognitif Bozukluk Sıçanların Hipokampüslerinde NLRP3 ve Nitrotirozin Seviyelerinin Artışı ile İlişkilidir
}

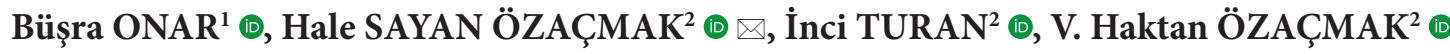 \\ ${ }^{1}$ Zonguldak Bülent Ecevit Üniversitesi, Sağlık Bilimleri Enstitüsü, Fizyoloji Anabilim Dalı, Zonguldak \\ ${ }^{2}$ Zonguldak Bülent Ecevit Üniversitesi, Tip Fakültesi, Fizyoloji Anabilim Dalı, Zonguldak
}

Bu makaleye yapılacak atıf: Onar B, Sayan Özaçmak H, Turan İ, Özaçmak VH. Diyabete Bağlı Kognitif Bozukluk Sıçanların Hipokampüslerinde NLRP3 ve Nitrotirozin Seviyelerinin Artışı ile İlişkilidir. Türk Diyab Obez 2019;3: 123-129.

\begin{abstract}
ÖZET
Amaç: Diyabetes mellitüs öğrenme ve hafıza bozukluğu ile birliktedir. Nöroinflamasyon sitokinlerin yapımını içeren diyabetin patofizyolojik bir işaretidir. Nitratif hasarın diyabetin patofizyolojik mekanizmasında yer aldığı ileri sürülmektedir. Nod-like receptor family pyrin domain-containing (NLRP), inflamazomlar IL-1 $\beta$ ve IL-18 yapımı ile inflamatuar cevabın gelişiminde önemlidir. Bu çalışmada diyabetik sıçanlarda NLRP3, IL-1 $\beta$, nitrotirozin düzeyleri ve kognitif fonksiyonlar arasındaki ilişkinin incelenmesi amaçlandı. Gereç ve Yöntemler: Sıçanlar rastgele 2 gruba ayrıldı: Kontrol ve diyabetik. Diyabet tek doz streptozotosin (STZ) uygulaması (60 mg/ $\mathrm{kg}$, intraperitoneal) ile oluşturuldu. Hayvanlar feda edilene kadar vücut ağırlıkları ve kan glukoz düzeyleri ölçüldü. Morris Su Labirenti (MWM) kognitif fonksiyonları değerlendirmek için kullanıld. Hipokampal NLRP3, IL-1 $\beta$ ve nitrotirozin düzeyleri ELISA yöntemiyle belirlendi.

Bulgular: Diyabetik grupta kan glukoz düzeylerinin yükseldiği gösterildi. NLRP3 ve nitrotirozin seviyelerinin diyabetik sıçanların hipokampüslerinde arttı̆̆ bulundu. Diyabet ile hipokampal IL-1 $\beta$ düzeylerinde istatistiksel olarak anlamlı değişiklik saptanmadı. MWM testinde diyabetik hayvanlar kontrollerle karşılaştırıldığında saklı platformu bulmak için daha fazla zaman harcadılar. Bu da öğrenme ve hafızanın anlamlı olarak bozulduğunu gösterdi ve bu bozukluk 5. günde istatistiksel olarak anlamlıydı.

Sonuç: Sonuçlarımız STZ ile oluşturulan diyabetin muhtemelen hipokampüsde NLRP3 seviyesini artırarak ve nitrozatif stres oluşumu ile sıçanlarda öğrenme ve hafıza bozukluğuna neden olduğunu göstermektedir.

Anahtar Sözcükler: Diyabet, Kognitiffonksiyon, NLRP3, Nitrotirozin

\section{Diabetes Incuced Cognitive Impairment is Associated with Increase of NLRP3 and Nitrotyrosine Levels in the Hippocampus of Rats}

\begin{abstract}
Aim: Diabets mellitus is associated with impaired learning and memory. Neuroinflammation is a pathophysiological hallmark of diabetes which include production of cytokines. It was suggested that nitrative injury has been implicated in the pathophysiologic mechanism of diabetes. Nod-like receptor family pyrin domain-containing (NLRP) inflammasomes are important in the development of inflammatory response through production of IL- $1 \beta$ and IL-18. In the present study was aimed to examine the relationship between NLRP3, IL-1 $\beta$, nitrotyrosine levels and cognitive functions in diabetic rats.

Material and Methods: The rats were randomly divided into 2 groups: control and diabetic. Diabetes was induced by a single intraperitoneal injection of $60 \mathrm{mg} / \mathrm{kg}$ of streptozotocin (STZ). Body weight and blood glucose level were measured until euthanasia. Morris water maze (MWM) was used to evaluate the cognitive function in rats. Hippocampal NLRP3, IL-1 $\beta$ and nitrotyrosine levels were measured.
\end{abstract}


Results: The results showed that the elevated blood glucose was obseved in diabetic group. NLRP3 and nitrotyrosine levels were found to be increased in hippocampus of diabetic rats. There was no statsitical significance in the hippocampal IL-1 $\beta$ level with diabetes. In the MWM, diabetic rats spent more time to find the submerged platform when compared with control rats, implying a significant impairment of learning and memory, and this impairment was found to be statistically signifcant at day 5 .

Conclusion: Our results indicate that STZ induced diabetes causes learning and memory impairment in rats probably by generating nitrosative stress and increasing NLRP3 level in the hippocampus.

Key Words: Diabetes, Cognitive function, NLRP3, Nitrotyrosin

\section{GİRIS}

Kronik hiperglisemi ile karakterize olan diyabetes mellitüs (DM) kognitif fonksiyon bozuklukları da dahil santral sinir sisteminde çeşitli komplikasyonlara neden olmaktadır. Öğrenme ve hafızadan sorumlu beyin bölgesi olan hipokampüs hiperglisemi ile tetiklenen oksidatif strese son derece duyarlıdır (1). Pek çok çalışma DM' nin öğrenme ve hafıza kayıpları ile karakterize kognitif fonksiyon bozukluklarına neden olduğunu bildirmektedir $(2,3)$. DM'nin merkezi sinir sistemi üzerinde zararlı etkileri olduğuna dair pekçok kanıtbulunmaktadır. Kardiyovasküler ve metabolik hastalıklar için bir risk faktörü olmasının yanı sıra DM'nin insanlarda kognitif bozuklukluklar, Alzheimer hastalı̆̆ı $(\mathrm{AD})$ ve demans gelişimi için bir risk faktörü oluşturduğu yönünde bulgular artmaktadır (4). DM'nin neden olduğu kognitif fonksiyon bozukluklarının diyabetli deneklerde normal deneklere göre 1.5 kat daha fazla olduğu artan kanitlarla ortaya konulmuştur (5).

Diyabetin neden olduğu öğrenme ve hafıza bozukluklarının moleküler mekanizması tam aydınlatılamamıștır. Kronik DM ile ortaya çıkan kognitif bozukluklar hipokampüsde sinaptik plastisite değişiklileri ile yakından ilişkilidir. Oksidatif stres artışı, antioksidan savunma enzimlerinde azalma ve nöroinflamasyonun gelişimi DM ile gelişen kognitif bozukluklardan sorumlu önemli patolojik faktörlerdir (6). DM'de hipokampal alanda nöron sayısında azalma, nöronal dejenerasyon ve apoptoz gözlenmektedir (4,5,7-9). Kan glukoz seviyesinde artış ve insülin sinyal eksikliği proksidan bir ortama yol açar. Glukoz oksijen ile reaksiyona girer ve kognitif fonksiyon bozukluğunun fizyopatolojisinde yer alan serbest oksijen radikallerinin (SOR) oluşumuna neden olur. Ayrica artan serbest oksijen radikalleri mitokondriyal hasarı da tetikler. Bunların sonucunda nöronal dejenerasyon ve ölüm gerçekleşmektedir (4).

Elde edilen kantlar, inflamasyonun deneysel diyabet modellerinde önemli bir rol oynadığını ve ayrıca depresyon, kognitif bozukluklar ve nöropati dahil olmak üzere nörodavranışsal bozuklukların gelişimine katkıda bulunduğunu göstermektedir $(10,11)$. Daha önceki çalışmalar diyabetin hipokampüsde IL-6, IL-1 $\beta$ gibi proinflamatuar sitokinlerin yapımını artırarak bu alandaki nöronların hasara yatkınlığını artırdığını göstermişlerdir (12-14).

İnflamazomlar kaspaz-1'i aktive ederek proinflamatuar sitokinlerin sentezi, inflamatuar hücre ölümü, SOR ve hasarla ilişkili moleküllere yanıt olarak piroptozun oluşumunu düzenleyen çoklu protein kompleksleridir. Şu ana kadar pek çok inflamazom türü tespit edilmesine karşın en iyi karakterize edilen ve çalışan inflamazom türü pirin domain'i içeren NOD- benzeri reseptör proteini 3(NLRP3)'dür. NLRP3 mikrobiyal olmayan tehlikeyi algılar ve çeşitli hastalık koşullarında steril inflamatuar cevaba neden olur. NLRP3 inflamazom, apoptoz ile ilişkili nokta benzeri adaptör protein içeren CARD(kaspaz aktive eden domain)(ASC), reseptör oligomerleri ve pro-kaspaz-1'den oluşur. SOR ile tetiklenen NLRP3'ün aktivasyonu kaspaz1 'in aracılığ 1 ile IL-1 $\beta$ ve IL-18 salınımını sağlar $(15,16)$. Glukoz yüksekliğinin NLRP3 inflamazom aracıllğ 1 ile steril inflamatuar cevap oluşturduğu saptanmıştır (17). NLRP3 inflamazomun Tip 2 diyabet, obezite ve erken dönem ateroskleroz gelişimi ile ilişkili olduğu belirtilmektedir. NLRP3 aktivasyonu ayrıca mitokondriyal disfonksiyon ve serbest oksijen radikallerinin yapımı ile yakından ilgili olduğu bulunmuştur (18). Ayrıca SOR-bağımlı NLRP3 aktivasyonu diyabetik hastalarda da gösterilmiştir (19).

DM'de kognitif fonksiyon değişimleri ile hipokampal nitrosatif stres, NLRP3 ve IL-1 $\beta$ arasındaki ilişki tam olarak araştırılmamıştır. $\mathrm{Bu}$ nedenle çalışmamızda diyabetik siçan hipokampüsünde NLRP3, IL-1 $\beta$ ve nitrotirozin düzeylerinin belirlenmesi ve bunun kognitif fonksiyonlarla ilişkisinin ortaya konulması amaçlanmıştır.

\section{GEREÇ ve YÖNTEM}

\section{Deney Hayvanları}

Çalışmada ağırlıkları 275-350 g ağırlığında 24 adet Wistar Albino cinsi erkek sıçanlar kullanıldı. Hayvanlar 12 saat aydınlık ve 12 saat karanlık ritminde sıcaklığın $20-25^{\circ} \mathrm{C}$ ve nemin \%50-60 olduğu ortamda standart yem ve çeşme suyu ile beslendi. Deneylerin tüm aşamaları için Bülent Ecevit Üniversitesi Hayvan Deneyleri Yerel Etik Kurulunun onayı alındı (Protokol no: 2017-15/09). 


\section{Diyabet Olușturulması}

Çalışmanın başlangıcında tüm sıçanların ağırlık ve kan şeker düzeyleri ölçüldü. Deneysel diyabet oluşturmak için streptozotosin (STZ) ( $0.1 \mathrm{M}$ sitrat tamponu içinde, $\mathrm{pH}$ 4.5) (Sigma-Aldrich Co, St. Louis, MO, A.B.D) 60mg/ $\mathrm{kg}$ olacak şekilde tek doz intraperitoneal (i.p) olarak uygulandı. STZ uygulamasından sonra hipoglisemiye bağlı komplikasyonları engellemek için enjeksiyondan sonraki ilk 48 saatte sıçanların içme suyuna \%5 oranında glukoz eklendi. STZ uygulamasından 72 saat sonra ölçülen açlık kan şeker değeri $250 \mathrm{mg} / \mathrm{dL}$ 'nin üzerinde olan hayvanlar diyabetik olarak kabul edilip çalışmaya bu hayvanlarla devam edildi (7).

Normoglisemik kontrol grubundaki sıçanlara ise $0,1 \mathrm{M}$ sitrat tamponu aynı hacimde i.p olarak uygulandı.

\section{Deney Grupları}

Her grupta eşit denek olacak şekilde deney hayvanları; normoglisemik kontrol (K) $(\mathrm{n}=8)$ ve diyabetik kontrol (DK) $(\mathrm{n}=12)$ olmak üzere iki gruba ayrıldı. STZ enjeksiyonundan sonra deney hayvanlarının kan glukoz düzeyi ve vücut ağırlığı takibi yapılmıştır. STZ enjeksiyonundan sonraki 4 haftalık dönemde diyabetik grupta 4 hayvan öldü.

Morris Su Labirenti (MWM) ile Uzaysal Öğrenme ve Hafızanın Değerlendirilmesi

Hipokampüse bağlı uzaysal öğrenme ve hafızanın değerlendirilmesi için MWM testi kullanıldı. Deney hayvanları deneyin 23. gününde saklı platformu bulmak için eğitildi. MWM düzeneği; çapı $150 \mathrm{~cm}$, derinliği $60 \mathrm{~cm}$ olan daire şeklinde bir havuz ve su yüzeyinin $2 \mathrm{~cm}$ altında kalacak şekilde 10x10 $\mathrm{cm}$ boyutunda bir platformdan oluşur. Deney öncesi MWM tankı $45 \mathrm{~cm}$ yüksekliğinde süt tozu ile opaklaştırılmış ve $24 \pm 1{ }^{\circ} \mathrm{C}$ 'de 1 sıtılmış çeşme suyu ile dolduruldu. Deneyin yapıldığ 1 odanın duvarlarına sıçanlar için ipucu oluşturabilecek farklı şekiller asıldı. Su tankı kuzey, batı, güney ve doğu olmak üzere olmak üzere dört farklı sanal kadrana ayrıldı. Eğitim yüzdürmelerinde sıçanlar her gün, günde 4 kez farklı yönlerden havuza bırakıldılar. Eğitim yüzdürmelerinin yapıldığı günlerde platform kuzeybatı (KB) kadranının ortasında tutuldu. Sıçanlara literatürde bildirildiği gibi saklı platformu bulmaları için 60 sn süre

Tablo 1: Grupların vücut ağırlıkları ve kan glukoz düzeyleri.

\begin{tabular}{lccc}
\hline & \multicolumn{2}{c}{ Vücut ağırlı̆̆ $\mathbf{~ ( g r )}$} & \multicolumn{2}{c}{ Kan glukoz (mg/dL) } \\
\hline Kontrol & $359,5(330-389)$ & $131(121-144)$ \\
\hline Diyabet & $260^{*}(223-311)$ & $435^{*}(400-455)$ \\
\hline
\end{tabular}

Değerler ortanca (min-maks) olarak verilmiștir. ${ }^{\star}$ Kontrol grubuna göre anlamlı farklılığı göstermektedir $(\mathrm{p}<0,001)$. tanındı. 60 saniye içinde platformu bulamayan sıçanlara yardım edilerek platformu bulmaları sağlanmış ve yaklaşık 15 saniye platform üzerinde kaldıktan sonra havuzun dışına alındı. Her bir yüzdürme esnasında saklı platformu bulma süreleri (escape latency) kaydedildi (4).

Hipokampus NLRP3, IL1- $\beta$ ve Nitrotirozin Düzeylerinin Ölçümü

Deney hayvanları MWM testi sonrasinda feda edilerek hipokampal alanları izole edildi. Dokuda NLRP3, IL1- $\beta$ ve nitrotirozin düzeylerinin belirlenmesi ticari kit (SunRed Biotech Company, Çin) kullanılarak ELISA yöntemiyle ölçüldü. Sonuçlar kit içinde yer alan standartlarla oluşturulan eğriye göre hesaplanarak konsantrasyonlar $\mathrm{ng} / \mathrm{ml}$ olarak belirlendi.

\section{İstatistiksel Analiz}

Gruplar arasındaki farklılık Mann Whitney U testi ile SPSS 22 paket program kullanılarak değerlendirildi. Değerler ortanca (min-maks) olarak verildi. Sonuçlara ait $\mathrm{p}$ değeri 0,05'den küçük olması durumunda istatistiksel olarak anlamlı kabul edildi.

\section{BULGULAR}

\section{Kan Glukoz Düzeyi ve Vüicut Ağırlığı}

Diyabetik gruba ait kan glukoz düzeylerinin normoglisemik kontrol grubuna göre yüksek olduğu saptandı. Vücut ağırlıkları diyabetik grupta kontrol grubuna göre istatistiksel olarak anlamlı azaldı (Tablo 1) $(\mathrm{p}=0,001)$.

\section{MWM Sonuçları}

Beş günlük eğitim süresinde saklı platformu bulma sürelerine ait bulgular Şekil 1'de gösterildi. Normoglisemik kontrol ve diyabetik gruplar arasında saklı platformu bulma süreleri açısından 5. günde istatistiksel olarak anlamlı farklılık bulundu. Saklı platformu bulma süresi diyabetik hayvanlarda kontrol grubuna göre 5. günde daha uzun olduğu saptandı (Tablo 2, Şekil 1) ( $\mathrm{p}=0,001)$.

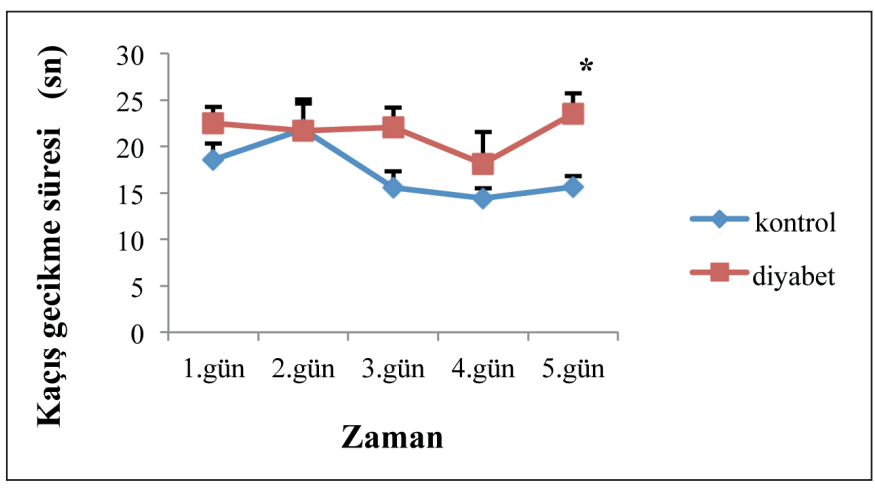

Şekil 1: MWM testinde gruplara ait saklı platformu bulma süreleri. 
Hipokampüs NLRP3, IL1- $\beta$ ve Nitrotirozin Düzeyleri

Hipokampal dokuda ölçülen NLRP3 değerleri diyabetik grupta kontrol grubu ile karşılaştırıldığında istatistiksel olarak anlamlı derecede arttığı saptandı (Tablo 3, Şekil 2) $(\mathrm{p}=0,001)$.

Hipokampal bölgede IL-1 $\beta$ değerleri açısından normoglisemik ve diyabetik hayvanlar karşılaştırıldığında iki grup arasındaki fark anlamlı değildir ( $\mathrm{p}=0,083)$; yani hipergliseminin etkisi ile IL-1 $\beta$ seviyesi değişmedi (Tablo 3 ).

Oksidatif stresi göstergesi olarak ölçülen nitrotirozin düzeylerinde diyabetik gruba ait hayvanlarda kontrol grubu ile karşılaştırıldığında istatistiksel olarak anlamlı bir artış saptand (Tablo 3, Şekil 3) ( $\mathrm{p}=0,010)$.

\section{TARTIŞMA}

Çalışmamızda yirmisekiz günlük diyabet sonrasında MWM ile değerlendirilen kognitif fonksiyonların bozulduğu belirlendi. Diyabetli deneklerde uzamış saklı platformu bulma süresi öğrenme ve hafızanın yavaşladığını göstermektedir. MWM'de elde edilen bu sonuçlar literatürdeki diğer yayınlarla benzerlik göstermektedir $(1,4,5,8,12)$. Bunun yanı

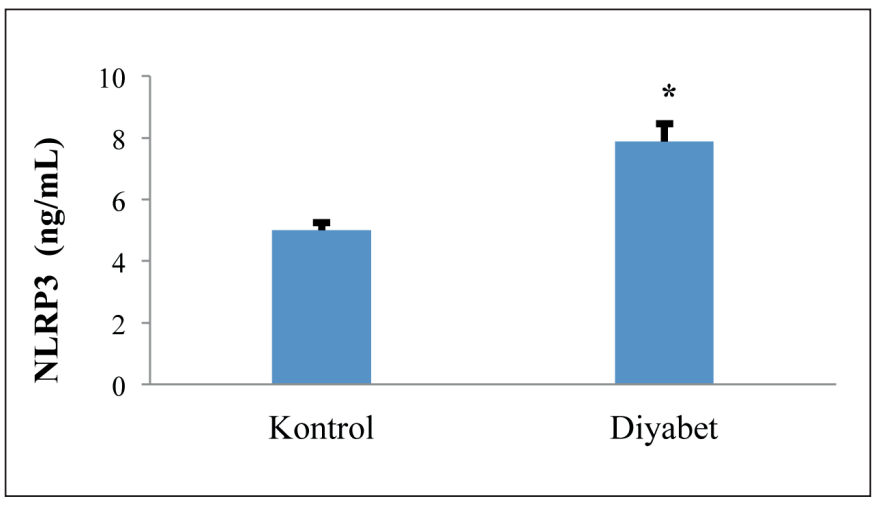

Şekil 2: Hipokampüs dokusunda NLRP3 (ng/mL) düzeyleri. sıra çalışmamızda hipokampüsde nitrotirozin ve NLRP3 seviyelerinde artış olduğu saptandı. Deneysel çalışmalarda DM'nin kognitif işlemlerle ilgili temel alan olan hipokampüsde negatif etkilerinin olduğu ve bu etkilerin oksidatif stres artışı, antioksidan enzim azalması ve apoptotik süreçlerin aktive olması ile gerçekleştiği bildirilmektedir $(1,4,5,8)$

DM kronik kompleks bir hastalıktır ve santral sinir sistemi üzerine bir takım olumsuz yan etkileri bulunmaktadır. Diyabetik hastaların azalmış kognitif performans gösterdikleri ve normal sağlıklı bireylere göre beyin görüntüleme çalışmalarında hacim azalması gibi anormalliklerin gözlendiği bildirilmektedir (11). 2006 yllında Mijnhout ve ark. bu alanda araştırma yapmayı kolaylaştırmak ve bu hastalığın tanınmasını güçlendirmek için yeni bir "diyabetle ilişkili kognitif azalma" yani "diyabetik ensefalopati" kavramını ortaya koymuşlardır (20).

Çeşitli çalışmalarda DM’nin vasküler demans ve AD'nin gelişiminde bir risk faktörü olduğu gösterilmektedir. Vasküler disfonksiyon, anormal glukoz metabolizması, bozulmuş insülin sinyali, SOR ve inflamasyon diyabetik ensefalopatinin patolojik sürecinde rol oynar $(6,21)$. Deneysel tip 1 diyabet

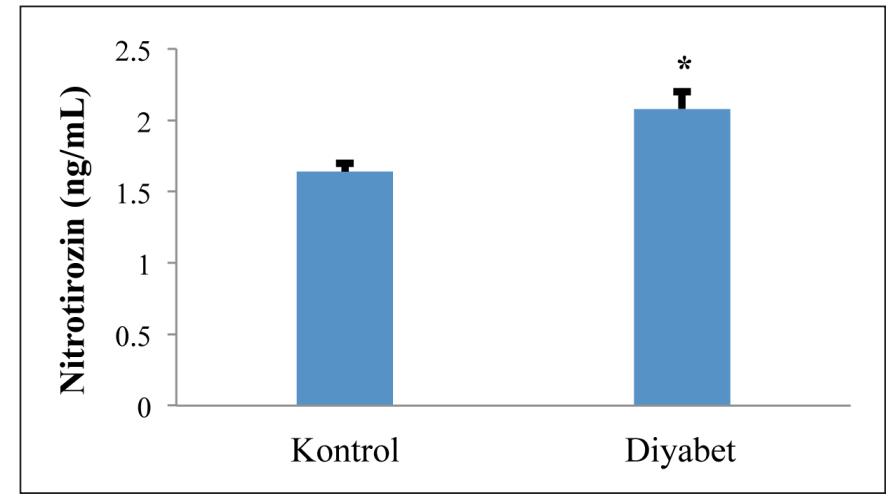

Şekil 3: Hipokampüs dokusunda nitrotirozin $(\mathrm{ng} / \mathrm{mL})$ düzeyleri.

Tablo 2: MWM testinde gruplar arası kaçış gecikme süreleri (sn).

\begin{tabular}{lccccc}
\hline & 1. Gün & 2. Gün & 3. Gün & 4. Gün & 5. Gün \\
\hline Kontrol & $18,5(16-27)$ & $23(14-30)$ & $16(12-29)$ & $14(9-26)$ & $15,5(10-20)$ \\
\hline Diyabet & $22,5(18-25)$ & $22(15-30)$ & $22,5(10-30)$ & $18,5(11-25)$ & $24^{*}(20-28)$ \\
\hline
\end{tabular}

Değerler ortanca (min-maks) olarak verilmiştir. ${ }^{*}$ Kontrol grubuna göre anlamlı farklılığı göstermektedir $(\mathrm{p}<0,001)$.

Tablo 3: Hipokampal alanda gruplar arası NLRP3, IL-1 beta ve nitrotrizon düzeyleri.

\begin{tabular}{lccc}
\hline & NLRP3 $(\mathbf{n g} / \mathbf{m L})$ & IL-1 Beta $(\mathbf{n g} / \mathbf{m L})$ & Nitrotrizon $(\mathbf{n g} / \mathbf{m L})$ \\
\hline Kontrol & $4,99(4,79-5,44)$ & $2,02(1,92-2,16)$ & $1,53(1,10-2,23)$ \\
\hline Diyabet & $8^{* *}(7-8,25)$ & $1,55(1,10-2,23)$ & $2,12^{\star}(1,99-2,22)$ \\
\hline
\end{tabular}

Değerler ortanca (min-maks) olarak verilmiștir. NLRP3: Nod- like reseptor pyrin domain-containing 3, IL-1 Beta: İnterlökin 1 beta. ${ }^{*}$ Kontrol grubuna göre anlamlı farklılığı göstermektedir $\left({ }^{* *} \mathrm{p}=0,001,{ }^{*} \mathrm{p}=0,010\right)$. 
modellerinde çok geniş çeşitlilikte nöronal değişikliklerin olduğu saptanmıştır. Bu patolojik anormallikler; sinaptik değişiklikler, dejenerasyon, artmış serebral mikrovasküler permeabilite ve nöronal kayıpları içermektedir ve bu etkiler kognitif bozukluklara ve demans gelişimindeki risk artışına yol açmaktadır (9).

Hipokampüs kısa ve uzun dönem hafıza ile ilişkili beyin alanıdır ve DM gibi metabolik hastalıklara son derece duyarlıdır (22). Çeșitli çalıșmalar hipokampüs üzerinde diyabetin negatif etkilere sahip olduğunu ve hipokampal nöronlarda apoptoza neden olduğunu göstermektedir. Hipokampüs striatum ve kortekse göre daha az kapiller yoğunluğa sahiptir ve bu nedenle vasküler disfonksiyona daha duyarlıdır. Diyabetle birlikte nöronal hasar, nöronal kayıp, serebral mikrovasküler hasarın yanısıra glial hücre aktivasyonu ve inflamatuar cevabın gelişimi kognitif fonksiyon bozuklukların gelişiminde önemli rol oynamaktadır (23).

MWM hipokampal lezyon modellerinde kognitif fonksiyonları değerlendirmek için sıklıkla tercih edilen bir testtir. Bu test problem çözme, gelişmiş seçici dikkat, dış dünyanın iç temsillerinin oluşturulması ve ilgili bilgilerin depolanması ve alınması gibi çok sayıda kognitif bileșeni içerir (9). STZ ile oluşturulan diyabetik sıçanlarda MWM testi ile değerlendirilen kognitif performans azalmasının 10 hafta sonra başladığ çalışmalarda ise 30 günlük diyabet süresi sonrasında MWM testinde öğrenme ve hafıza bozukluklarının olduğu gösterilmektedir $(1,25,26)$. Bizim çalıșmamızda bu çalışmalara benzer şekilde diyabet oluşturulmasından 4 hafta sonra daha erken dönemde öğrenme ve hafiza bozukluklarının geliştiği saptandı.

Hiperglisemi diyabetik komplikasyonların oluşumunda temel patofizyolojik faktördür. İntrasellüler hiperglisemi mitokondriyal SOR'un yapımına neden olarak proinflamatuar sitokinlerin yapımında artışa ve resiprokal olarak sitokinlerin yapımının artışı SOR yapımında artışa neden olmaktadır. Bu döngüden dolayı oksidatif stres ve inflamatuar süreçler diyabette kognitif bozuklukların gelişiminde temel rol oynamaktadır. Deneysel diabetik siçan beyinlerinde IL-6, IL1- $\beta(11-13)$ ve TNF- $\alpha(6,11)$ gibi sitokinlerin artışının MWM testinde performans azalması ile ilişkili olduğu gösterilmiştir.

Çalışmamızda diyabetik sıçan hipokampüsünde NLRP3 düzeylerinin normoglisemik kontrol grubuna göre yüksek olduğu tespit edildi. Bu bulgu ile birlikte MWM testinde saptanan öğrenme ve hafiza performansinda azalma NLRP3'ün diyabetle oluşan kognitif fonksiyon bozukluklarının gelişiminde rol oynadığını göstermektedir. Zhai ve ark. (2018) yaptıkları çalışmada diyabetik farelerin hipokampüslerinde NLRP3 ve IL- $\beta$ düzeylerinin artarken kognitif fonksiyonların azaldığını göstermişlerdir. Ayrıca aynıçalışmada NLRP3 inhibitörünün kullanımının diyabetik farelerde bu etkileri tersine çevirdiği gözlenmiştir (21). Bizim çalışmamızda elde ettiğimiz bulgular bu çalışmada saptanan diyabetik farelerde hipokampal NLRP3 düzeylerinin artışı ile benzerlik göstermektedir. Ancak biz çalışmamızda IL- $\beta$ düzeylerinde diyabetik sıçanlarda nomoglisemik kontrollere göre anlamlı bir artış tespit etmedik. Literatürde 7 günlük diyabet sonrası IL-1 $\beta$ artışının olduğunu gösteren bulgular yer almaktadır (27). Çalışmamızda STZ uygulamasından 28 gün sonra hipokampüsde IL- $1 \beta$ seviyelerinde kontrol grubu ile karşılaştırıldığında istatistiksel olarak anlamlı bir farklılık saptanmadi. Bu durumun diyabetin süresi, kullanılan hayvan türü ve ölçüm metoduna bağlı olarak değişebileceğini düşünmekteyiz.

NLRP3 diyabette önemli inflamatuar hedef olarak görülmektedir. Hipokampüsde NLRP3 yapımının olmadığ 1 farelerde kognitif fonksiyonların korunduğu gösterilmiștir (28). İskemik beyin hasarı sonrasında NLRP3 inhibitörünün kullanımının diyabetik sıçanlarda nörovasküler yeniden şekillenme ve kognitif fonksiyonların korunmasında etkili olduğu görülmüştür (29). NLRP3 aktivasyonu ve diyabete bağlı komplikasyonlar arasında yakından ilişki olduğu saptanmıştır (30). Menu ve Vince (2011) diyabet ve komplikasyonlarının gelişiminde NLRP3 anormal aktivasyonu ve IL-1ß'nın yapımının artışının etkisini tanımlamışlardır (31). NLRP3'ün diyabetik retinopatinin gelişiminde retinal hücrelerde permeabilite ve apotozu artırarak etkili olduğu bildirilmiştir $(15,32)$.

Diyabetle ortaya çıan nörodejenerasyonda inflamatuar cevap, SOR'un üretimi ve reaktif nitrojen türlerinin oluşumu arasında yakından bir ilişki bulunmaktadır (33). Ayrıca son çalışmalarda diyabetin SOR üretimindeki artışa neden olarak apoptotik nöronal ölümle sonuçlandığı ortaya konmuştur. Nitrik oksit (NO) superoksit radikali ile peroksiniti oluşturarak nitrozatif stresin oluşumuna neden olur. Nitrozatif stres nitrik oksit sentaz yapımının ve nitrit seviyesininde artışa, astrosit aktivasyonu ve protein nitrasyonuna yol açarak kognitif bozukluklara ve nörodejenerasyona neden olmaktadır (34). Çalışmamızda oksidatif stresin bir göstergesi olarak hipokampal alanda ölçülen peroksinitritle tirozin reaksiyon ürünü olan nitrotirozin düzeyleri diyabetik grupta normoglisemik kontrollere göre anlamlı yüksek bulundu. Nitrotirozin seviyesinin diyabetik grupta artışının MWM ile değerlendirilen kognitif bozukluklarda etkili olabileceğini düşünmekteyiz. Sadraie ve ark. (2019) nitrotirozin seviyesindeki artışın kognitif fonksiyon bozuklukların gelişiminde etkili olduğunu göstermişlerdir (35). Benzer şekilde Alzheimer hastalığı modellerinde de nitrotirozin 
seviyesinin arttığı bulunmuștur. Tirozinlerin nitrasyonu hafiza bozukluğunu proteinlerin fosforilasyonu ve konformasyonel değişimini inhibe etmesiyle ortaya çıkarmaktadır (35). Kelly-Cobbs ve ark. (2012) diyabetik sıçanlarda hem plazma hem de orta serebral arterde nitrotirozin düzeylerinde artışların olduğunu göstermişlerdir (36). Bu bulgular da gözönüne alınırsa çalışmamızda elde ettiğimiz diyabetik koşullarda hipokampal alanda artan nitrotirozin düzeyinin öğrenme ve hafıza bozukluklarının oluşumunda rol oynadığını göstermektedir.

Sonuçlarımız STZ ile oluşturulan diyabetik koşullarda hipokampal alanda NLRP3 ve nitrotirozin düzeylerinin artışının diyabete bağlı olarak gözlenen öğrenme ve hafıza bozukluklarının fizyopatolojisinde yer aldığını göstermektedir.

\section{KAYNAKLAR}

1. Rababa'h AM, Mardini AN, Alzoubi KH, Ababneh MA, Athamneh RY. The effect of cilostazol on hippocampal memory and oxidative stress biomarkers in rat model of diabetes mellitus. Brain Res. 2019; 1715:182-187.

2. Zhang S, Yuan L, Zhang L, Li C, Li J. Prophylactic use of troxerutin can delay the development of diabetic cognitive dysfunction and improve the expression of NRF2 in the hippocampus on STZ diabetic rats. Behav Neurol. 2018;2018:18.

3. Wang JQ, Yin J, Song YF, Zhang L, Ren YX, Wang DG, Gao LP, Jing YH. Brain aging and AD-like pathology in streptozotocininduced diabetic rats. J Diabetes Res. 2014; 2014:1-12.

4. Omidi G, Karimi SA, Rezvani-Kamran A, Monsef A, Shahidi S, Komaki A. Effect of coenzyme Q10 supplementation on diabetes induced memory deficits in rats. Metab Brain Dis. 2019; 34(3):833-840.

5. Wang XP, Ye P, Lv J, Zhou L, Qian ZY, Huang YJ, Mu ZH, Wang X, Liu XJ, Wan Q, Yang ZH, Wang F, Zou YY. Expression changes of NMDA and AMPA receptor subunits in the hippocampus in rats with diabetes induced by streptozotocin coupled with memory impairment. Neurochem Res. 2019;44(4):978-993.

6. Ahshin-Majd S, Zamani S, Kiamari T, Kiasalari Z, Baluchnejadmojarad T, Roghani M. Carnosine ameliorates cognitive deficits in streptozotocin-induced diabetic rats: Possible involved mechanisms. Peptides. 2016;86:102-111.

7. Baydas G, Reiter RJ, Yasar A, Tuzcu M, Akdemir I, Nedzvetskii VS. Melatonin reduces glial reactivity in the hippocampus, cortex, and cerebellum of streptozotocin-induced diabetic rats. Free Radic Biol Med. 2003;35(7):797-804.

8. Delkhosh-Kasmaie F, Farshid AA, Tamaddonfard E, Imani M. The effects of safranal, a constitute of saffron, and metformin on spatial learning and memory impairments in type-1 diabetic rats: Behavioral and hippocampal histopathological and biochemical evaluations. Biomed Pharmacother. 2018; 107:203-211.
9. Sadeghi A, Hami J, Razavi S, Esfandiary E, Hejazi Z. The effect of diabetes mellitus on apoptosis in hippocampus: Cellular and molecular aspects. Int J Prev Med. 2016;7:1-17.

10. Vargas R, Rincón J, Pedreañez A, Viera N, HernándezFonseca JP, Peña C, Mosquera J. Role of angiotensin II in the brain inflammatory events during experimental diabetes in rats. Brain Res. 2012;1453:64-76.

11. Li R, Zang A, Zhang L, Zhang H, Zhao L, Qi Z, Wang H. Chrysin ameliorates diabetes-associated cognitive deficits in Wistar rats. Neurol Sci. 2014; 35(10):1527-1532.

12. Datusalia AK, Sharma SS. Amelioration of diabetes-induced cognitive deficits by GSK-3 $\beta$ inhibition is attributed to modulation of neurotransmitters and neuroinflammation. Mol Neurobiol. 2014; 50(2):390-405.

13. Zhou XY, Zhang F, Hu XT, Chen J, Tang RX, Zheng KY, Song YJ. Depression can be prevented by astaxanthin through inhibition of hippocampal inflammation in diabetic mice. Brain Res. 2017; 1657:262-268.

14. Wang J, Wang L, Zhou J, Qin A, Chen Z.The protective effect of formononetin on cognitive impairment in streptozotocin (STZ)-induced diabetic mice. Biomed Pharmacother. 2018; 106:1250-1257.

15. Chen W, Zhao M, Zhao S, Lu Q, Ni L, Zou C, Lu L, Xu X, Guan H, Zheng Z, Qiu Q. Activation of the TXNIP/NLRP3 inflammasome pathway contributes to inflammation in diabetic retinopathy: A novel inhibitory effect of minocycline. Inflamm Res. 2017;66(2):157-166.

16. Liu D, Zeng X, Li X, Mehta JL, Wang X. Role of NLRP3 inflammasome in the pathogenesis of cardiovascular diseases. Basic Res Cardiol. 2017; 113(1):5.

17. Zhang Y, Lv X, Hu Z, Ye X, Zheng X, Ding Y, Xie P, Liu Q. Protection of Mcc950 against high-glucose-induced human retinal endothelial cell dysfunction. Cell Death Dis. 2017;8(7):e2941.

18. Rovira-Llopis S, Apostolova N, Bañuls C, Muntané J, Rocha M, Victor VM. Mitochondria, the NLRP3 inflammasome, and sirtuins in type 2 diabetes: New therapeutic targets. Antioxid Redox Signal. 2018; 29(8):749-791.

19. Qiu YY, Tang LQ. Roles of the NLRP3 inflammasome in the pathogenesis of diabetic nephropathy. Pharmacol Res. 2016; 114:251-264.

20. Mijnhout GS, Scheltens P, Diamant M, Biessels GJ, Wessels AM, Simsek S, Snoek FJ, Heine RJ. Diabetic encephalopathy: A concept in need of a definition. Diabetologia. 2006; 49(6):1447-1448.

21. Zhai Y, Meng X, Ye T, Xie W, Sun G, Sun X. Inhibiting the NLRP3 inflammasome activation with MCC950 ameliorates diabetic encephalopathy in $\mathrm{db} / \mathrm{db}$ mice. Molecules. 2018; 23(3): 1-14

22. Chesnokova V, Pechnick RN, Wawrowsky K. Chronic peripheral inflammation, hippocampal neurogenesis, and behavior. Brain Behav Immun. 2016; 58:1-8.

23. Hardigan T, Ward R, Ergul A. Cerebrovascular complications of diabetes: Focus on cognitive dysfunction. Clin Sci. (Lond) 2016;130(20):1807-1822. 
24. Biessels GJ, Kamal A, Urban IJ, Spruijt BM, Erkelens DW, Gispen WH. Water maze learning and hippocampal synaptic plasticity in streptozotocin-diabetic rats: Effects of insulin treatment. Brain Res. 1998; 800:125-135.

25. Yön B, Belviranlı M, Okudan N. The effect of silymarin supplementation on cognitive impairment induced by diabetes in rats. J Basic Clin Physiol Pharmacol. 2019. doi.org/10.1515/ jbcpp-2018-0109

26. Gocmez SS, Şahin TD, Yazir Y, Duruksu G, Eraldemir FC, Polat S, Utkan T. Resveratrol prevents cognitive deficits by attenuating oxidative damage and inflammation in rat model of streptozotocin diabetes induced vascular dementia. Physiol Behav. 2019; 201:198-207.

27. Liu X, Liu M, Mo Y, Peng H, Gong J, Li Z, Chen J, Xie J. Naringin ameliorates cognitive deficits in streptozotocininduced diabetic rats. Iran J Basic Med Sci. 2016;19(4):417422.

28. Zhuang J, Wen X, Zhang YQ, Shan Q, Zhang ZF, Zheng GH. TDP-43 upregulation mediated by the NLRP3 inflammasome induces cognitive impairment in 2 2',4,4'-tetrabromodiphenyl ether (BDE-47)-treated mice. Brain Behav Immun. 2017;65:99110.

29. Ward R, Li W, Abdul Y, Jackson L, Dong G, Jamil S, Filosa J, Fagan SC, Ergul A. NLRP3 inflammasome inhibition with MCC950 improves diabetes-mediated cognitive impairment and vasoneuronal remodeling after ischemia. Pharmacol Res. 2019; 142:237-250.

30. Song W, Wei L, Du Y, Wang Y, Jiang S. Protective effect of ginsenoside metabolite compound $\mathrm{K}$ against diabetic nephropathy by inhibiting NLRP3 inflammasome activation and NF- $\mathrm{B} / \mathrm{p} 38$ signaling pathway in high-fat diet/ streptozotocin-induced diabetic mice. Int Immunopharmacol. 2018; 63:227-238.
31. Menu P, Vince JE. The NLRP3 inflammasome in health and disease: The good, the bad and the ugly. Clin Exp Immunol. 2011; 166:1-15.

32. Loukovaara S, Piippo N, Kinnunen K, Hytti M, Kaarniranta K, Kauppinen A. NLRP3 inflammasome activation is associated with proliferative diabetic retinopathy. Acta Ophthalmol. 2017; 95(8):803-808.

33. Oliveira WH, Nunes AK, França ME, Santos LA, Lós DB, Rocha SW, Barbosa KP, Rodrigues GB, Peixoto CA. Effects of metformin on inflammation and short-term memory in streptozotocin-induced diabetic mice. Brain Res. 2016; 1644:149-160.

34. Ramírez-García G, Palafox-Sánchez V, Limón ID. Nitrosative and cognitive effects of chronic L-DOPA administration in rats with intra-nigral 6-OHDA lesion. Neuroscience. 2015; 290:492-508.

35. Sadraie S, Kiasalari Z, Razavian M, Azimi S, Sedighnejad L, Afshin-Majd S, Baluchnejadmojarad T, Roghani M. Berberine ameliorates lipopolysaccharide-induced learning and memory deficit in the rat: Insights into underlying molecular mechanisms. Metab Brain Dis. 2019; 34(1):245-255.

36. Kelly-Cobbs AI, Prakash R, Coucha M, Knight RA, Li W, Ogbi SN, Johnson M, Ergul A. Cerebral myogenic reactivity and blood flow in type 2 diabetic rats: Role of peroxynitrite in hypoxia-mediated loss of myogenic tone. J Pharmacol Exp Ther. 2012; 342(2):407-15 
